\title{
BUDAYA DAN WILLINGNESS TO ACCEPT (WTA) KOMPENSASI ATAS ALIH FUNGSI LAHAN PERTANIAN DI KABUPATEN GIANYAR: KASUS BANJAR BANGKIANSIDEM, DESA KLIKI, TEGALALANG
}

\author{
I Made Endra Kartika Yudha ${ }^{1}$ \\ Made Suyana Utama ${ }^{2}$
}

Fakultas Ekonomi Dan Bisnis Universitas Udayana, Bali, Indonesia ${ }^{1,2}$

Email: kartikayudha@unud.ac.id ${ }^{1}$

\begin{abstract}
Environmental damage and the conversion of agricultural land have become problems that will affect human life. Industrial development and the construction of tourist accommodation such as hotels and restaurants have caused various impacts. The environmental impact of tourism activities also occurs in Gianyar Regency, the indicator is the conversion of agricultural land functions. For this reason, it is necessary to know the value of willingness to accept (WTA) to compensate for the conversion of agricultural land in Gianyar Regency by taking and cultural factors that explain the value of this WTA. The average value of WTA for compensation for the conversion of community land in Kliki Village is Rp.217,500.- per month. A cultural factor is formed that is used to explain the value of WTA. These cultural factors are formed by 4 variables and have one variable with the highest loading factor which is the average time of customary activities.
\end{abstract}

Keywords: WTA; Culture; Agricultural

\begin{abstract}
ABSTRAK
Kerusakan lingkungan dan alih fungsi lahan pertanian telah menjadi masalah yang akan berdampak kepada kehidupan manusia. Pembangunan industri dan pembangunan akomodasi wisata seperti hotel dan restauran telah menyebabkan berbagai dampak. Dampak lingkungan dari kegiatan pariwisata juga terjadi di Kabupaten Gianyar, Indikatornya adalah alih fungsi lahan pertanian. Untuk itu perlu diketahui nilai willingness to accept (WTA) untuk kompensasi alih fungsi lahan petanian di Kabupaten Gianyar dengan mengambil dan faktor budaya yang menjelaskan nilai WTA ini. Nilai rata-rata WTA atas kompensasi alih fungsi lahan masyrakat di Desa Kliki adalah Rp.217.500.- per bulan. Terbentuk 1 faktor budaya yang digunakan untuk menjelaskan nilai WTA. Faktor budaya tersebut dibentuk oleh 4 variabel dan memiliki satu variabel dengan loading faktor tertinggi yakni rata-rata waktu kegiatan adat.
\end{abstract}

Kata kunci: WTA; Budaya; Pertanian 


\section{PENDAHULUAN}

Pencermaran dan kerusakan lingkungan telah terjadi sangat cepat. Pertumbuhan ekonomi dan pertambahan jumlah penduduk telah memberikan dampak terhadap peningkatan pencermaran dan kerusakan lingkungan diseluruh dunia. Keberhasilan pembangunan dan pertumbuhan ekonomi yang dilaksanakan dengan memanfaatkan sumber daya alam banyak menyisakan dampak positif terhadap lingkungan (Sriyanto, 2007). Kerusakan lingkungan semakin menjadi perhatian semenjak terjadinya globalisasi secara besar-besaran, keterbukaan negara-negara yang sebelumnya menutup diri dari dunia internasional. Globalisasi telah mendorong perusahaan multinasional melakukan kegiatan ekonomi melewati lintas batas semenjak 1970 yang bekerja secara ekspansif dan ekspoitatif sehinga ada indikasi mengabaikan dampak yang ditimbulkan oleh dampak perusahaan mutlinasional yang menghasilkan persoalan lingkungan seperti pencemaran tahan, air, udara, kerusakan hutan, dan tanaman (Amri, 2011).

Kegiatan perusahaan multinasional yang bergerak dibidang industri dan pertambangan akan sangat berdampak negatif terhadap kerusakan lingkungan. Kegiatan industri dan pemanfaatan sumber daya alam yang terjadi secara menerus akan menimbulkan eksternalitas negatif bagi kelangsungan hidup dan kerusakan lingkungan (Astuti et al., 2014). Dampak kerusakan lingkungan tidak hanya menyebabkan kerusakan pada sumber daya alam, namun juga menyebabkan dampak negatif terhadap kesehatan manusia. Dampak lingkungan terhadap kesehatan masyarakat dan kehidupan telah menjadi masalah seperti di wilayah 
tambang PT. Freeport yakni pencemaran drainase batu asam juga mengamcam kehidupan karena mencemari pasokan air lokal (Astuti, 2018).

Terdapat berbagai indikator kerusakan lingkungan, salah satu indikator kerusakan lingkungan adalah erosi tanah, erosi tanah adalah proses perpindahan tanah atau batuan dari satu tempat yang lebih tinggi ke tempat yang lebih rendah akibat dorongan air, angin, atau gaya gravitasi, sehingga tingginya erosi tanah akan menyebabkan produktifitas hasil pertanian menjadi rendah karena lahan tidak mengandung koloit akibat adanya erosi (Yudistira et al., 2011). Selain erosi, terdapat masalah lain yang sedang mempengaruhi lingkungan pertanian yakni alih fungsi lahan. Penyebab alih fungsi lahan yang paling besar adalah memenuhi kebutuhan ekonomi keluarga, ibadah haji, usaha bisnis, pengobatan, pembayaran hutang, renovasi rumah, tukar tambah lahan, dan pembagian waris (Janah et al., 2017).

Kebijakan dapat mempengaruhi alih fungsi lahan, seperti pembangunan jalan raya dan jalan tol, pembangunan bandara, akitivitas kereta api dan pembangunan kawasan wisata, diantara berbagai kebijakan yang paling berpengaruh signifikan adalah pembangunan jalan, semakin baik akses jalan suatu wilayah maka semakin tinggi alih fungsi lahan pertanian di daerah tersebut (Kusumastuti et al., 2018). Putri (2015) menemukan bahwa luas lahan perumahan, jumlah industri, PDRB, dan panjang jalan memiliki pengaruh positif dan siginifikan terhadap alih fungsi lahan, dan jumlah penduduk dan investasi mimiliki pengaruh positif namun tidak siginifikan, temuan ini memperlihatkan bahwa jalan atau akses 
merupakan hal penting dalam merubah lahan pertanian ke bentuk lain. Tanpa ada akses jalan maka akan sulit sekali memanfaatkan menjadi bentuk lain seperti bangunan atau rumah tinggal mengingat hal ini menjadi acuan penting dalam menentukan bagaimana cara pembangunan dan nilai jual tanah tersebut, mengingat tanpa akses jalan maka tanah tersebut tidak dapat dimanfaatkan secara maksimal dalam bentuk non - pertanian.

Alih fungsi lahan pertanian menjadi lahan terbangun untuk aktivitas nonpertanian hal ini menyebabkan terjadi perubahan struktur sosial dan ekonomi dalam masyarakat, perubahan ini berupa kekerabatan antar warga yang memudar dan bagi petani yang kehilangan lahan pertaniannya berupa penurunan pendapatan karena tingkat pendidikan dan keterampilan para petani yang terbatas yang menyebabkan mereka tidak mampu mengakses pekerjaan formal (Dewi \& Rudianto, 2013). Hal serupa juga ditemukan oleh Janah et al., (2017) bahwa alih fungsi lahan pertanian mempengaruhi secara signifikan alih pekerjaan dan persedian pangan keluarga, Mereka para tidak petani tidak memiliki keterampilan sulit untuk masuk sektor industri sehingga akhirnya ini akan menambah kemiskinan baru dipedesaan.

Perkembangan ekonomi dan pariwisata juga menyebabkan alih fungsi lahan pertanian tidak dapat dihindarkan di Pulau Bali, termasuk Kabupatenm Gianyar. Kontribusi jasa di bisnis pariwisata memberikan dampak pada perekonomian dan pendapatan masrayarakat, tentu juga memberikan dampak kepada lingkungan hidup di Kabupaten Gianyar. Berdasarkan Gambar 1 diketahui bahwa sektor penyedia akomodasi dan makan minuman merupakan sektor yang memberikan 
kontribusi tertinggi pada pembentukan PDRB di Kabupaten, dengan total kontribusi sebesar 26 persen, sisanya disumbangkan oleh sektor pertanian, industri, konstruksi. Hal ini memunculkan permintaan atas akomodasi setiap tahunnya. Pesatnya pertumbuhan sarana akomodasi memunculkan fakta bahwa sebagian besar akomodasi pariwisata tersebut dibangun diatas lahan yang dahulunya lahan pertanian, ini mengindikasikan bahwa pariwisata memberikan pengaruh besar terhadap masyarakat dan berdampak terhadap sosial-budaya masyarakat baik secara tangible dan maupun intangible (Dipayana \& Sunarta, 2015).

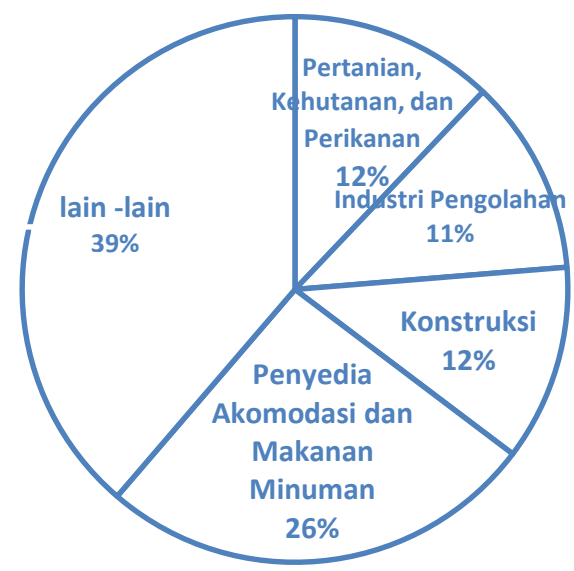

\section{Gambar 1.}

4 Sektor Besar Berkontribusi diatas 10 Persen Terhadap PDRB Kabupaten Gianyar Tahun 2019 dengan Harga Berlaku

Perkembangan pariwisata memberikan bukan hanya dampak terhadap pendapatan, pertumbuhan ekonomi, lingkungan hidup, namun juga memberikan dampak kepada budaya yang ada di Kabupaten Gianyar. Pariwisata yang memberikan pengaruh terhadap alih fungsi lahan telah memberikan dampak kepada 
nilai dan kegiatan budaya. Individu yang telah menjual lahan pertanian dan individu mengalihfungsikan lahan pertanian menyebabkan individu tersebut keluar dari seka subak atau kelompok subak, sehingga ini mengancam kelestarian budaya yang telah ada, berkurangnya seka subak berdampak kepada hilangnya ritual keagamaan dan budaya yang secara rutin dilakukan setiap 6 bulan sekali (Dipayana dan Sunarta, 2015). Berbagai dampak yang terjadi diatas, membutuhkan kebijakan dan perencanaan khusus. Dampak yang berupa biaya dan manfaat yang dinikmati masyarakat bukan konsumen, menujukkan adanya eksternalitas, seringkali manfaat dan biaya eksternal ini tidak dicerminkan dalam harga pasar dan estimasi nilai biaya dan manfaat ini lebih sulit (Sugianto \& Fikri, 2016). Eksternalitas dapat berupa manfaat dan biaya, saat eksternalitas menjadi biaya, maka ini berupa pencemaran dan kerusakan lingkungan akibat perubahan penggunaan lahan seperti alih fungsi lahan pertanian, maka hal ini perlu upaya valuation atau penilaian yang baik.

Jika nilai barang publik seperti udara bersih, air yang tidak tercemar, atau keanekaragaman hayati tidak dapat dihasilkan dari pengamatan perilaku individu melalui harga pasar (preferensi yang diungkapkan), nilai barang ini biasarnya ditentukan oleh tanggapan terhadap pertanyaan survei (preferensi yang dinyatakan atau disebutkan), hal ini disebut survei contingent valuation $(\mathrm{CV})$, survei $\mathrm{CV}$ merupakan metode survei sangat penting karena menyediakan informasi mengenai nilai "moneter" dari alam atau lingkugan yang membantu para politikus menentukan kebijakan (Liebe et al., 2011). Dalam survei CV ditujukan untuk mengetahui kesedian membayar kompensasi yang disebut willingness to pay (WTP) dan kesediaan menerima pembayaran kompennsasi willingness to accept 
(WTA) dalam satuan moneter tertentu. Nilai WTP dan WTA akan memberikan gambaran mengenai preferensi kesedian konsumen dan produsen untuk meningkatkan kualitas lingkungan dengan menggunakan pertanyaan seberapa besar konsumen atau produsen bersedia membayar (WTP) yang dikenakan untuk meningkatkan kualitas lingkungan atau seberapa besar mereka mau menerima kompensasi dari biaya lingkungan yang mengalami kerusakan (Tanrivermis, 1988).

Nilai WTA dan WTP nilainya akan berbeda karena terjadi peningkatan nilai loss aversion (Schriber et al., 2016). loss aversion adalah kondisi psikologi seseorang lebih sensitif terhadap kerugian dari pada keuntungan yakni rasa kehilangan sesuatu pernah dimiliki melebih rasa senang yang dimiliki ketika mendapatkannya (Wisadanto \& Baihaqi, 2016). Semakin besar rasa kehilangan yang dinilai akan dialami maka nilai loss aversion akan semakin tinggi. Masalah ini sangat sering terjadi pada saat menilai sebuah kerugian yang tenga dihadapi. Hal ini bisa menyebabkan terjadi perbedaan nilai antara WTA dan WTP seperti yang ditemukan oleh Schriber et al., (2016).

Untuk menjelaskan nilai WTA dan WTP digunakan berbagai jenis variabel. Tanrivermis (1998) melakukan penelitian mengenai WTP dan WTA dan menggunakan beberapa variabel untuk menjelaskan WTA dan WTP dengan variabel jumlah pendapatan rumah tangga selama sebulan, umur responden, tingkat pendidikan, jenis gender, jumlah anggota keluarga, level pembangunan pada area tersebut, dan rata-rata limbah dapur yang dihasilkan, dan ditemukan bahwa variabel yang paling berpenguh secara positf adalah tingkat pendapatan, dimana yang memiliki tingkat pendapatan yang lebih tinggi bersedia membayar lebih banyak 
untuk pajak yang dikenakan untuk perbaikan lingkungan. Lindhjem \& Mitani (2012) menjelaskan nilai WTA dari kompensasi yang diterima pemilik hutan untuk melakukan pelestarian hutan, pada penelitian ini digunakan beberapa varibael bebas untuk menjelaskan nilai WTA yakni luas hutan, produktifitas hutam, kekayaan hayati yang merupakan variabel dummy, tingkat kerusakan kayu, tinggal di satu kecamatan dengan lokasi hutan, jenis kelamin, umur, tingkat pendidikan, tingkat pendapatan, keanggotaan dalam organisasi kepemilikan hutan, organisasi penangkapan ikan, ekspektasi terhadap keuntungan dari program, skenario lelang yang digunakan, jumlah penjualan kayu kurang dari 5 tahun terakhir, ditemukan bahwa dari seluruh variabel tersebut hanya luas hutan yang berpengaruh secara siginifikan. Selanjutnya Chilton et al., (2011) meneliti mengenai variabel yang menjelaskan WTA dengan menggunakan beberapa variabel bebas antara lain durasi, jenis kelamin, jumlah anggota keluarga, pendidikan, tipe pekerjaan, pengalaman atas komplian, persepsi kesehatan saat ini, dan ditemukan bahwa umur, pendidikan, tipe pekerjaan pengalaman komplain merupakan variabel yang berpengaruh terhadap WTA.

Casey et al., (2008) meneliti mengenai WTA untuk menerima kompensasi untuk resiko lingkungan akibat pengiriman minyak, penelitian ini menggunakan beberapa variabel bebas untuk menjelaskan nilai WTA ini yakni dengan menggunakan variabel yakni harga, pendapatan, polusi air, kepemilikan properti, jenis kelamin, umur, penambahan jumlah sekolah, penambahan jumlah guru, perbaikan kesehatan. Pendapatan dan umur merupakan dua variabel yang berpengaruh secara signifikan. Stephen (2015) melakukan penelitian serupa 
mengenai nilai WTA untuk menerima pembayaran konservasi dari jasa ekosistem di Gunung Kilimanjaro menggunakan beberapa variabel bebas seperti umur kepala rumah tangga, jumlah anggota keluarga, tingkat pendidikan, kolasi tempat tinggal, luas lahan kepemilikan hutan, total pendaptan dari keluarga pemilik hutan, persepsi mengenai pentingnya ekosistem, lokasi, ditemukan bahwa umur, jumlah anggota keluarga, persepsi mengenai pentingnya ekosistem, total pendapatan berpengaurh signifikan terhadap WTA.

Pada penelitian yang telah dilakukan sebelumnya mengenai WTA dan WTP secara umum menggunakan beberapa variabel bebas yang sering digunakan antara lain seperti usia, pendapatan, jumlah anggota keluara, lokasi tempat tinggal, dan beberapa hal lain yang terkait dengan skenario dan tema penelitian. Belum banyak yang menggunakan variabel kebudayaan. Variabel kebudayaan dianggap sangat penting karena kebudayaan merupakan hasil dari sebuah kebisaan yang dilakukan oleh sebuah masyarakat. Tentu ini menjadi sangat penting untuk diketahui karena banyak budaya-budaya dalam pertanian khususnya di Kabupaten Gianyar, Provinsi Bali menentukan perilaku kehiudapan masyarakat pertanian. Budaya menjadi sangat penting karena ini terkait dengan kebiasaan yang akan berkaitan dengan psikologi seseorang. Ini dikuatkan dengan hubungan antara WTA dan WTP dengan loss aversion yang merupakan yang merupakan gejala psikologi. Untuk itu penelitian ini berusaha menjelaskan faktor budaya yang menjelasakn nilai WTA. Ini penting dilakukan karena budaya merupakan sesuatu yang tidak dapat diukur dan masih sedikit orang menjelaskan hubungan budaya dan WTA. 
Kebudayaan adalah sebuah cara hidup yang dikembangkan oleh sekolompok masyrakat untuk memenuhi kebutuhan hidupnya seperti pengumpulan bahan kebendaan, pola organisasi sosial, cara berperilaku, ilmu pengetahuan, kepercayaan, serta kegiatan lain yang berkembang dalam interaksi manusia (Miharja, 2013). Lima hal penting dalam budaya bali adalah seni, pola hidup (terdiri atas sistem kebahasaan, sistem kekerabatan/menyabaraya), sistem kelembagaan (adat, dan kelompok desa), sistem kemasyarakatan, sistem kepercayaan (sakral, sekulerisasi, dan profan) dimana hal ini dipengaruhi oleh keagamaan di Bali (Subawa, 2018). Apabila diamati, lima hal penting dalam budaya secara spesifik dapat berbentuk norma adat, gotong royong dalam rangka memberikan bantuan atau lebih sering disebut metulung atau marenging, Seka sebagai kelompok tradisional, kegiatan budaya seperti ngaben, ngotonin, dan lain sebagainya yang secara berkalan dilakukan sebagai bagian dari budaya Bali. Budaya - budaya yang terkandung dalam kehidupan masyarakat di Bali sangat penting terlebih lagi budaya pertanian yang sudah semakin banyak ditinggalkan karena lahan pertanian yang sudah beralih fungsi menjadi tempat tinggal atau fasilitas akomodasi pariwisata. Alih fungsi lahan juga terjadi di Banjar Bangkiangsidem, Desa Kliki, Tegalalang, Kabupaten Gianyar. Untuk itu penting dilakukan berikut ini. Penelitian ini akan menjelaskan faktor budaya apa yang menjelaskan nilai WTA untuk menerima kompensasi atas alih fungsi lahan di Banjar Bangkiangsidem, Desa Kliki dan menghitung nilai WTA atas kompensasi atas alih fungsi lahan pertanian, Tegalalang Kabupaten Gianyar, Provinsi Bali. Penelitian ini dilakukan di Tahun 2019 di Banjar Bangkiangsidem, Desa Kliki. Banjar Bangkiangsidem ini 
merupakan salah satu dari banyak desa yang mengalami masalah alih fungsi lahan di Kabupaten Gianyar. Hal ini terjadi karena perkembangan pariwisata yang cepat, sehingga lahan peruntukan untuk akomodasi wisata mengalami peningatan permintaan dengan cepat juga.

\section{METODE PENELITIAN}

Penelitian ini dilakukan pada tahun 2019 dengan mengambil lokasi penelitian di Banjar Bangkiansidem, Desa Kliki, Tegalalng, Kabupaten Gianyar. Penelitian dilakukan di Banjar Bangkiangsidem, Desa Kliki karena di Banjar Bangkiangsidem ini terjadi pembangunan akomodasi pariwisata ditengah lahan pertanian, mengingat desa ini cukup dekat dengan Desa Ubud. Penelitian ini menggunakan survei $\mathrm{CV}$ untuk menghitung nilai WTA atas kompensasi atas alih fungsi lahan pertanian, alat survei yang digunakan adalah kuesioner untuk mendapatkan jawaban dari responden. Uji Validitas dan Reabilitas merupakan uji instrumen yang penting. Uji Validitas dapat menggunakan metode confirmatory factor analysis (CFA) yang terdiri atas uji Kaiser-Meyer Olkin (KMO) dan Barlett Test, uji ini merupakan uji validitas isi dan kosntruk (Melati \& Dharmmesta, 2011). Uji Reabilitas menggunakan metode Alfa Cronbach. Responden merupakan warga adat dan dinas Banjar Bangkiangsidem, Desa Kliki. Penelitian ini menggunakan 80 responden warga yang tinggal di Banjar Bangkiangsidem tersebut. Penelitian ini mengambil sampel secara acak dan responden yang memiliki dan pernah memiliki lahan pertanian kendatipun sudah dijual atau dipindahtangankan atau dibuah menjadi bentuk lain. Terdapat beberapa variabel yang digunakan dalam untuk 
membentuk faktor budaya baru antara lain rata-rata jumlah kegiatan adat setiap bulan, jumlah seka tradisional yang masih diikuti, rata-rata jam kegiatan untuk setiap kegiatan adat, kualitas gotong-royong dalam kegiatan adat, penerapan aturan adat dalam setiap kegiatan adat. Rata-rata jumlah kegiatan adat setiap bulan diukur dengan menghitung jumlah kegiatan adat terkait upacara setiap bulannya, umumnya kegiatan ini cukup reguler dilakukan seperti odalan atau ngaben dihitung dengan satuan kali kegiatan. Jumlah seka (kelompok) tradisional yang masih diikuti adalah jumlah kelompok tradsional yang diikuti oleh responde sebagai anggota kelompok maupun pengurus kelompok diatur dengan kelembagaan tradisional dihitung dengan jumlah kuantitas tertentu yang dihitung dengan satuan kelompok. Rata-rata jam kegiatan untuk setiap kegiatan adalah rata-rata lama berlangsungnya kegiatan upacara, persiapan, atau lainnya yang dihitung dengan satuan menit atau jam.

Kualitas gotong royong adalah diukur dengan kualitas kegiatan yang semakin cepat dan dipermudah, yang diukur dengan skala likert yaitu 1 untuk sangat tidak berkualitas, 2 untuk kurang berkualitas, 3 untuk cukup berkualitas, 4 untuk berkualitas, 5 untuk sangat berkualitas. Penerapan aturan adat adalah mengukur kegiatan yang tetap menggunakan aturan adat yang masih seperti lestari semenjak generasi dan tidak menggunakan aturan adat yang berlaku, cara mengukur dengan dummy, dimana 0 adalah tidak menggunakan aturan adat dan 1 adalah untuk menggunakan aturan adat untuk setiap kegiatan. Variabel budaya diatas merupakan variabel yang dapat diukur dan merupakan hasil dari pengamatan empiris peneliti, ini merupakan bagian dari budaya seseuai dengan unsur budaya 
yang dijelaskan oleh Subawa (2018). Untuk nilai WTA, responden diberikan pertanyaan jumlah rupiah atau moneter yang akan bersedia diterima atas kompensasi perubahan lahan atau alih fungsi lahan disekitar lahan pertanian atau lingkungan milik responden, dengan nilai rupiah terkecil adalah Rp.50.000.- dan untuk tertinggi bebas ditentukan oleh responden.

Penelitian ini menggunakan analisis faktor untuk mengentahui faktor budaya apa saja yang mampu menjelaskan nilai WTA kompensasi akibat terjadi alih fungsi lahan di Banjar Bangkiangsidem, Desa Kliki. Analisis faktor adalah suatu cara menjelaskan suatu himpunan variabel berdasarkan dimensi yang lebih umum (Puspitasari dkk., 2014). Analasis faktor atau analisi komponen bertujuan utama untuk mereduksi data dan mengintepretasikan sebai suatu variabel baru yang berupa variabel bentukan (Daely et al., 2013; Verdian, 2019). Analisis faktor atau juga disebut sebagai analisis komponen utama digunakan untuk menjelaskan struktur matriks varian kovarian dari suatu set variabel melalui kombinasi linear variabel tersebut (Delsen et al., 2017). Selain digunakan sebagai analisis komponen, analisis faktor yang terdiri dari uji Uji Kasier Meyer Olkin (KMO) dan Bartlett test dapat digunakan sebagai ujia validitas (Melati \& Dharmmesta, 2011). Dalam tahapan analisis faktor, terdapat beberapa uji yang harus dihitung. Tahapan pertama, variabel harus di uji dengan Uji Kasier Meyer Olkin (KMO) dan Bartlett test. Uji KMO menunjukkan kecukupan atau kelayakan data yang dipakai dalam penelitian dan seberapa berguna data dalam penelitian, nilai KMO harus diatas 0,5 agar layak digunakan dan valid (Hernikawati \& Sensuse, 2016). 
Uji Bartletts Test adalah uji statistik yang dipergunakan untuk menguji apakah variabel tidak saling berkorelasi dalam populasi atau dengan kata lain uji ini memastikan matrik korelasi antar variabel yang digunakan dalam faktor tidak menghasilkan matriks indentitas agar valid, sehingga uji ini wajib signifikan pada alpha lima persen (Daely et al., 2013). Selanjutnya ada uji dengan mengukur nilai Measure of Sampling Adequacy (MSA), dimana nilai ini untuk mengetahui ada tidaknya hubungan (korelasi) yang signifikan antara variabel bebas yang digunakan didalam faktor (Puspitasari dkk., 2014). Apabila nilai MSA dibawah nol koma lima maka, variabel tersebut wajib untuk dihilangkan didalam atau di drop dari proses analisi faktor. Tahapan selanjutnya adalah mengukur nilai communalities, nilai ini menentukan hubungan antara variabel dan faktor yang dibentuk dan variabel mampu menjelaskan faktor yang dibentuk, semakin besar nilai communalities, maka semakin baik (Delsen dkk., 2017). Tahapan selanjutnya adalah mengukur nilai eigenvalue, apabila nilai eigen yang bernilai lebih dari satu terdapat dua buah angka yang bernilai lebih dari 1, maka ini berarti terbentuk 2 faktor, dan apabila terdapat hanya satu eigenvalue dengan nilai diatas satu, maka terbentuk satu faktor saja (Puspitasari dkk., 2014). Nilai persentase varian dari eigen menunjukkan kemampuan kemampuan faktor menjelaskan variasinya, semakin besar nilai variannya maka sebaik faktor tersebut. Tahap terakhir adalah menghitung komponen matrik dengan mengukur nilai loading faktor. Loading faktor ini menujukkan korelasi antara variabel dengan faktor dibentuk. Semakin besar nilai loadingnya maka semakin kuat korelasi variabel dengan faktor yang dibentuk, sehingga variasi yang dijelaskan semakin baik. 


\section{HASIL DAN PEMBAHASAN}

Untuk mengetahui faktor-faktor apa yang menjelasakan mengenai nilai WTA atas kompensasi alih fungsi lahan pertanian di Banjar Bangkiangsidem, Desa Kliki, maka terdapat beberapa tahapan dari memulai memilih dan melakukan droping untuk menghasilkan faktor yang ideal. Uji pertama yang wajib dipenuhi adalah nilai Kasier - Meyer - Olkin (KMO) dan nilai sig dari Bartlett's Test. Untuk nilai KMO dari faktor budaya diketahui bahwa nilainya nol koma tujuh, nilainya ini diatas nilai nol koma lima. Berarti Uji KMO sudah dipenuhi, sehingga bisa dilanjut untuk tahap berikutnya serta layak untuk difaktorkan. Selanjutnya nilai sig dari Bartlett's Test bernilai nol koma nol ini menujukkan signifikan dengan taraf lima peren yang memiliki arti bahwa korelasi antar variabel yang dijadikan input dalam perhitungan tidak akan menyebabkan matriks identitas dan faktor cukup efektif untuk digunakan. Berikut disajikan pada Tabel 1 nilai KMO dan Sig dari Bartlett's Test.

Tabel 1.

Kaiser- Meyer - Olkin Measure of Sampling Adequacy (KMO)

\begin{tabular}{llr}
\hline KMO of Sampling Adequacy & $\mathbf{0 , 7 1 0}$ \\
\hline Bartlett's Test of Sphericity & Approx. Chi-Square & 61,959 \\
& df & 10 \\
& Sig. & 0,000 \\
\hline
\end{tabular}

Sumber: Data diolah (2020)

Nilai KMO dan nilai sig Bartlett's Test sudah memenuhi syarat, sehingga sudah dianggap efektif dan layak untuk digunakan, untuk itu dilanjutkan ke tahap 
berikutnya yakni memastikan nila anti image correlation sudah diatas nol koma lima. Apabila terdapat nilai anti image correlation yang bertanda "a", maka variabel tersebut patut untuk dihilangkan karena derajat korealasi antar variabel relatif lemah. Pada penelitian ini seluruh nilai anti image matrix pada Tabel 2 menujukkan nilainya diatas nol koma lima. ini artinya bahwa variabel ini memiliki korelasi kuat antar variabel. Untuk itu maka tahapan analisis faktor berikutnya dapat dilaksanakan dengan memastikan communalities sesuai dengan batas yang ditentukan

Tabel 2.

Anti Image Matrix : Measure of Sampling Adequacy (MSA)

\begin{tabular}{|c|c|c|c|c|c|c|}
\hline Correlation & Faktor & $\begin{array}{c}\text { Jumlah } \\
\text { Kegiatan } \\
\text { budaya } \\
\text { Setiap } \\
\text { Bulan }\end{array}$ & $\begin{array}{c}\text { Jumlah } \\
\text { Seka } \\
\text { Tradisional } \\
\text { (kelompok } \\
\text { tradisional) } \\
\text { Yang Masih } \\
\text { diikuti }\end{array}$ & $\begin{array}{l}\text { Rata- } \\
\text { rata jam } \\
\text { kegiatan } \\
\text { untuk } \\
\text { segiatan } \\
\text { adat }\end{array}$ & $\begin{array}{l}\text { Tingkat } \\
\text { Gotong } \\
\text { Royong } \\
\text { dalam } \\
\text { Kegiatan } \\
\text { Adat }\end{array}$ & $\begin{array}{c}\text { Penerapan } \\
\text { aturan } \\
\text { adat } \\
\text { dalam } \\
\text { setiap } \\
\text { kegiatan } \\
\text { adat }\end{array}$ \\
\hline \multirow{5}{*}{$\begin{array}{l}\text { Anti-image } \\
\text { Correlation }\end{array}$} & $\begin{array}{l}\text { Jumlah } \\
\text { kegiatan } \\
\text { budaya } \\
\text { setiap bulan } \\
\end{array}$ & $0,758^{\mathrm{a}}$ & $-0,12$ & $-0,219$ & 0,024 & $-0,077$ \\
\hline & $\begin{array}{l}\text { Jumlah seka } \\
\text { tradisional } \\
\text { (kelompok } \\
\text { tradisional) } \\
\text { yang masih } \\
\text { diikuti }\end{array}$ & $-0,12$ & $0,721^{\mathrm{a}}$ & $-0,311$ & $-0,272$ & $-0,18$ \\
\hline & $\begin{array}{l}\text { Rata-rata } \\
\text { jam kegiatan } \\
\text { untuk } \\
\text { kegiatan } \\
\text { adat }\end{array}$ & $-0,219$ & $-0,311$ & $690^{\mathrm{a}}$ & $-0,342$ & 0,049 \\
\hline & $\begin{array}{l}\text { Kualitas } \\
\text { gotong } \\
\text { royong } \\
\text { dalam } \\
\text { kegiatan } \\
\text { adat }\end{array}$ & 0,024 & $-0,272$ & $-0,342$ &, $715^{\mathrm{a}}$ & $-0,003$ \\
\hline & $\begin{array}{l}\text { Penerapan } \\
\text { aturan adat } \\
\text { dalam setiap } \\
\text { kegiatan } \\
\text { adat }\end{array}$ & $-0,077$ & $-0,18$ & 0,049 & $-0,003$ & $0,632^{\mathrm{a}}$ \\
\hline
\end{tabular}

Sumber: Data diolah (2020) 
Nilai communalities merupakan Uji yang menunjukkan bahwa menggambarkan hubungan variabel dengan faktor yang dibentuk masuk kategori rendah atau tinggi, apabila nilai communalities terbentuk diatas nol koma lima maka dapat dikatakan hubungan variabel dengan faktor yang dibentuk kuat, sehingga mampu menjelaskan faktor terbentuk. Untuk penelitian ini diketahui bahwa nilai communalities lima variabel relatif kuat. Varibel ini yang cukup kuat menjelaskan faktor yang dibentuk dibandingkan variabel lain adalah jumlah seka tradisional (kelompok tradisional) yang masih diikuti. Keanggotaan seka ini terkait dengan keterlibatan warga masyarakat dalam sebuah kelembagaan tradisional untuk mencapai suatu tujuan, seka tradisional ini biasanya terditi atas seka manyi, seka semal, seka gong, seka drama, seka ebat, seka tampah semal dan berbagai jenis seka lainnya yang erat hubungan dengan kegiatan budaya dan adat di sebuah desa yang sudah ada semenjak generasi sebelumnya. Nilai communalities telah memiliki nilai diatas nol koma lima sehingga variabel berikut layak untuk masuk tahap selanjutnya, yaitu untuk menentukan berapa faktor yang yang akan terbentuk dari penelitian ini.

Tabel 3.

Communalities

\begin{tabular}{lcc}
\hline \multicolumn{1}{c}{ Nama } & Initial & Extraction \\
\hline Jumlah kegiatan budaya setiap bulan & 1 & 0,633 \\
\hline Jumlah seka tradisional (kelompok tradisional) yang masih diikuti & 1 & 0,626 \\
\hline Rata-rata jam kegiatan untuk kegiatan adat & 1 & 0,640 \\
\hline Kualitas gotong royong dalam kegiatan adat & 1 & 0,539 \\
\hline Penerapan aturan adat dalam setiap kegiatan adat & 1 & 0,580 \\
\hline Sumber:
\end{tabular}

Sumber: Data diolah (2020)

Unsur dari Uji communalities sudah terpenuhi, untuk itu perlu diketahui berapa faktor yang terbentuk dari penelitian ini. Untuk itu digunakan Uji intial 
eigenvalues. Pada penelitian ini diketahui bahwa hanya terbentuk satu jenis faktor saja, karena faktor tersebut satu-satunya memiliki nilai eigenvalues diatas satu yaitu dua koma satu, dengan total nilai variance sebesar empat puluh tiga persen. Nilai eigen dua koma satu, diatas nilai satu memiliki arti bahwa faktor yang terbentuk hanya satu, sisanya bernilai dibawah satu. Variabel ini juga memiliki nilai variance sebesar empat puluh tiga persen, memiliki arti bahwa faktor dapat menjelaskan variasi sebesar empat puluh tiga persen, sisanya dijelaskan oleh faktor lain yang tidak ikut dinilai. Hal ini dapat terjadi karena budaya itu terbentuk dari berbagai jenis kebiasaan seperti perilaku, aturan, kelompok, makanan, bahasa, agama dan lain sebagainya yang terkait. Nilai eigen dan nilai variance disajikan Tabel 4.

Tabel 4.

Initial Eigenvalues

\begin{tabular}{ccccccc}
\hline No & Total & $\begin{array}{c}\text { \% of } \\
\text { Variance }\end{array}$ & $\begin{array}{c}\text { Cumulativ } \\
\text { e \% }\end{array}$ & Total & $\begin{array}{c}\text { \% of } \\
\text { Variance }\end{array}$ & $\begin{array}{c}\text { Cumulativ } \\
\text { e \% }\end{array}$ \\
\hline 1 & 2,176 & 43,518 & 43,518 & 2,176 & 43,518 & 43,518 \\
2 & 0,986 & 19,710 & 63,228 & & & \\
3 & 0,848 & 16,959 & 80,187 & & & \\
4 & 0,521 & 10,424 & 90,611 & & & \\
5 & 0,469 & 9,389 & 100,000 & & & \\
\hline
\end{tabular}

Sumber: Data diolah (2020)

Pada penelitian ini dilakukan diketahui faktor yang terbentuk adalah satu faktor dengan beberapa variabel. Sehingga seluruh variabel masuk kedalam satu faktor. Untuk mengetahui variabel mana yang memiliki korelasi paling kuat. Ratarata jam kegiatan untuk kegiatan adat merupakan variabel yang memiliki korelasi yang paling kuat dibandingkan variabel lainnya. 
Tabel 5.

\section{Component Matrix}

\begin{tabular}{lc}
\hline \multicolumn{1}{c}{ Component } & $\mathbf{1}$ \\
\hline Rata-rata jumlah kegiatan adat setiap bulan & 0,532 \\
Jumlah seka tradisional (kelompok tradisional) yang masih diikuti & 0,791 \\
Rata-rata jam kegiatan untuk setiap kegiatan adat & 0,800 \\
Kualitas gotong royong dalam kegiatan adat & 0,734 \\
Penerapan aturan adat dalam setiap kegiatan adat & 0,797 \\
\hline
\end{tabular}

Sumber: Data diolah (2020)

Berdasarkan wawancara dengan masyarakat yang berada di Banjar Bangkiangsidem, Desa Kliki, menuturkan bahwa waktu untuk alokasi kepada kegiatan adat dan budaya sangat penting. Ukuran waktu akan mempengaruhi jumlah alokasi antara bekerja dan istirahat. Semakin banyak alokasi yang digunakan untuk kegiatan adat seperti tedun dan metulung (gotong royong wajib dan memberikan bantuan tenaga secara sukarela) untuk kegiatan upacara manusa, pitra, atau dewa yadnya. Ini tentu akan mempengaruhi jumlah jam kerja baik itu bekerja di sektor pertanian atau yang lain, sehingga pada saat sektor pertanian menjadi sudah tidak menarik karena terjadi alih fungsi lahan, maka tentu ini akan menjadi acuan penting dalam menerima kompensasi. Karena apabila seseorang sudah tidak bekerja di sektor pertanian, maka otomatis harus pindah ke sektor lain seperti jasa pariwisata atau lainnnya. Kemungkinan besar sektor tersebut di luar desa, ini akan sangat berkoreasi dengan pendapatan dan nilai WTP atas alih fungi lahan pertanian. Selanjutnya nilai koefesien alfa menujukkan nilai 0,752, ini berarti instrumen yang digunakan telah relibel. 
Tabel 6.

Koefesien Cronbach Alfa

\begin{tabular}{lcc}
\hline & Koefesien & Nilai \\
\hline & Cronbach's Alfa & 0,752 \\
\hline Sumber: Data diolah (2020) &
\end{tabular}

Untuk nilai WTA untuk menerima kompensasi kerusakan lingkungan dari delapan puluh responden memiliki nilai rata-rata WTA sebesar dua ratus tujuh belas ribu lima ratus rupiah per bulan bagi penduduk yang terdampak atas alih fungsi lahan terjadi ke dalam bentuk fasilitas akomodasi pariwisata. Nilai minimum WTA atas alih fungsi yang terjadi adalah delapan puluh ribu per bulan, dan nilai maksimum pembayaran adalah satu juta lima ratus ribu rupiah per bulan. Nilai ratarata ini merupakan salah satu cerminan kondisi seseorang untuk menerima sebuah kerusakan lingkungan atas yang terjadi karena perubahan alih fungsi lahan pertanian. Nilai ini dapat menjadi masukan kepada para pengambil kebijakan untuk menentukan jumlah kompensasi yang diterima jika terjadi alih fungsi lahan pertanian, khususnya kepada pengelola pura subak. Karena pada saat lahan pertanian telah habis, maka pura subak itu sendiri tidak akan memiliki fungsinya lagi secara sediakala, sehingga pengelolaan pura sangat terganggu dan memberikan kebijakan bagi masyarakat yang terdampak pula. Berikut Tabel 7 disajikan nilai rata-rata, minimum, maksimum, dan total WTA untuk kompensasi alih fungsi lahan pertanian di Banjar Bangkiangsidem, Desa Kliki, Kecamatan Tegalalang, Kabupaten Gianyar. 
Tabel 7.

Nilai WTA untuk Menerima Kompensasi Alih Fungsi Lahan di Desa Kliki

\begin{tabular}{rrrrrr}
\hline No & N & Minimum & Maksimum & Total & Rata-rata \\
\hline Nilai & 80 & 80.000 & 1.500 .000 & 17.400 .000 & 217.500 \\
WTA & & & & &
\end{tabular}

Namun penelitian ini masih memiliki kekurangan sehingga perlu dilakukan penelitian lebih lanjut, karena penelitian ini tidak menjelaskan bagaimana pengaruh antara WTP dengan faktor budaya. Sehingga melalui penelitian ini maka, diharapkan penelitian selajutnya dapat menjelaskan bagaimana pengaruh nilai budaya terhadap nilai WTP atas kerusakan lingkungan yang terjadi.

\section{SIMPULAN DAN SARAN}

Berdasarkan hasil dan pembahasan diatas, terdapat dua simpulan yang dapat dituangkan dalam penelitian ini. Simpulan penelitian ini adalah sebagai berikut. 1). Faktor budaya terbentuk oleh beberapa variabel yakni Rata-rata jumlah kegiatan adat setiap bulan, jumlah seka tradisional (kelompok tradisional) yang masih diikuti, rata-rata jam kegiatan untuk setiap kegiatan adat, kualitas gotong royong dalam kegiatan adat, penerapan aturan adat dalam setiap kegiatan adat. Faktor budaya terbentuk terdiri atas satu faktor budaya, dengan nilai loading faktor tertinggi dari varoabel rata-rata jam kegiatan. Variabel ini memiliki korelasi yang kuat dalam menjelaskan faktor budaya. Ukuran waktu akan mempengaruhi jumlah alokasi antara bekerja dan istirahat. Semakin banyak alokasi yang digunakan untuk kegiatan adat seperti tedun dan metulung (gotong royong wajib dan memberikan bantuan tenaga secara sukarela) untuk kegiatan upacara manusia, pitra, atau dewa yadnya. Ini tentu akan mempengaruhi jumlah jam kerja baik itu bekerja di sektor 
pertanian atau yang lain, sehingga pada saat sektor pertanian menjadi sudah tidak menarik karena terjadi alih fungsi lahan, maka tentu ini akan menjadi acuan penting dalam menerima kompensasi. 2). Nilai WTA rata-rata yang bersedia diterima atas terjadinya alih fungsi lahan pertanian adalah dua ratus tujuh belas ribu lima ratus ruoiah per bulan dengan nilai minimum WTA adalah delapan puluh ribu rupiah. Nilai ini dapat digunakan untuk mengambil sebuah kebijakan atas dampak alih fungsi lahan pertanian kepada kelompok petani seperti subak dan masyarakat sekitar.

Penelitian ini masih memiliki kelemahan karena belum mengukur pengaruh antara faktor budaya dengan nilai WTA yang diperoleh, ini merupakan kelemahan pada penelitian ini, untuk itu perlu dilakukan penelitian lebih lanjut mengenai hal ini. Penelitian terkait nilai WTA dan faktor budaya perlu diteliti kembali karena hal ini relatif kuat, mengingat budaya terbentuk atas kebiasaan-kebiasaan manusia yang diawariskan. Kebiasaan ini juga merupakan hasil dari kegiatan dan psikologi manusia itu sendiri. Untuk ini penting sekali dilakukan penelitian lanjut mengenai WTA dan budaya.

\section{REFERENSI}

Amri. Ulil. 2011. Globalisasi dan Dampak Terhadap Lingkungan dan Keamanan Manusia di Asia Pasifik: Kasus China dan Paua Nugini. Jurnal Kajian Wilayah. 2(1), 56-71.

Astuti, A. D. 2018. Impilasi Kebijakan Indonesia dalam Menangani Kasus Pencemaran Lingkungan oleh PT. Freeportter Terhadap Keamanan Manusia di Mimika Papua. Journal of Internasional Relations. 4(3), 547-555.

Astuti, T., Parenta, T., \& Paddu, H. (2014). Peranan Kegiatan Industri Pengolahan Terhadap Pencemaran Lingkungan di Sulawesi Selatan. Jurnal Analisis, 
Juni, 3(1), 49-56.

Casey, J. F., Kahn, J. R., \& Rivas, A. A. (2008). Willingness to accept compensation for the environmental risks of oil transport on the Amazon: A choice modeling experiment. Ecological Economics, 67(4), 552-559.

Chilton, S. M., Jones-Lee, M. W., McDonald, R. L., \& Metcalf, H. R. T. (2011). Eliciting reliable willingness-to-accept responses. White Paper, Newcastle Discussion Papers in Economics: ISSN, 1361-1837.

Daely, K., Sinulingga, U., Manurung, A. 2013. Analisis Statistik Faktor-faktor yang Mempengaruhi Indeks Prestasi Mahasiswa. Sanitia Matematika. 1(5), 483494.

Delsen, M. S. N. V., Wattimena, A. Z., Saputri, S. D. 2017. Penggunaan Metode Analisis Komponen Utama Untuk Mereduksi Faktor-faktor Inflasi di Kota Ambon. Jurnal Ilmu Matematika terapan. 11(2), 109-118.

Dewi, N. K. \& Rudianto, I. 2013. Indentifikasi Alih Fungsi Lahan Pertanian dan Kondisi Sosial Ekonomi Masyarakat Daerah Pinggiran di Kecamatan Gunungpati Kota Semarang. Jurnal Wilayah dan Lingkungan. 1(2), 175-188.

Dipayana, A. \& Sunarta, I. N. 2015. Dampak Pariwisata Terhadap Alih Fungsi Lahan di Desa Tibubeneng Kecamatan Kuta Utara Kabupaten Badung (Studi Sosial-Budaya). Jurnal Destinasi Budaya. 3(2), 58-66.

JANAH, R. A., Trisetyo Eddy, B., \& Dalmiyatun, T. (2017). Alih fungsi lahan pertanian dan dampaknya terhadap kehidupan penduduk di kecamatan sayung kabupaten demak. Jurnal Agrisocionomics, 1(1), 1-10.

Kusumastuti, A. C., Kolopaking, L. M., \& Barus, B. (2018). Faktor yang Mempengaruhi Alih Fungsi lahan Pertanian Pangan di Kabupaten Pandeglang. Sodality, Jurnal Sosiologi Pedesaan, 6(2).

Liebe, U., Preisendörfer, P., \& Meyerhoff, J. (2011). To pay or not to pay: Competing theories to explain individuals' willingness to pay for public environmental goods. Environment and Behavior, 43(1), 106-130. http://doi: $10.1177 / 0013916509346229$.

Lindhjem, H. \& Mitani, Y. 2012. Forest Owner Willingness to Accept Compensation for Voluntary Conservation: A Contingent Valuation Approach. Journal of Forest Economics. 18, 290-302.

Metali, Rika. \& Dharmmesta, B. S. 2011. Pengaruh Persepsi Tentang Advertorial Produk Kesehatan di Koran Pada Sikap Konsumen. Jurnal Manajemen dan Pelayanan Farmasi. 1(2), 111-117. 
Miharja, Deni. 2013. Adat, Budaya, Dan Agama Lokal : Studi Gerakan Ajeg Bali Agama Hindu Bali. Jurnal Studi Agama dan Pemikiran Islam. 7(1), 53-77.

Puspitasari, E., Mukid, M. Abdul., Sudarmo. 2014. Perbandingan Analisis Faktor Klasik dan Analisis Faktor Robust Untuk Data Inflasi Kelompok Bahan Makanan di Jawa Tengah. Jurnal Gaussian. 3(3), 343-352.

Putri, Z. R. 2015. Analisis Penyebab Alih Fungsi Lahan Pertanian ke Lahan NonPertanian Kabupaten di Provinsi di Jawa Tengah 2003-2013. Eko-Regional: Jurnal Pembangunan Wilayah. 10(1), 17-22.

Stephen, C. Willingness to Accept Payment For Conservation Of Ecosystem Service in Mount Kilimanjaro, Tanzania and Taita Hills. Disertation. Tanzania: University Of Agriculture.

Subawa, I. M. P. 2018. Bali dalam Dinamika Masyarakat dan Kebudayaan di Tengah Perkembangan Pariwisata. Pariwisata Budaya. 3(1), 95-109.

Sugianto, Catur \& Fikri, Aula Ahmad Hafidah Saiful. 2016. Ekonomi Sumber Daya Alam. Jogjakarta: UPP STIM YKPN.

Tanrivermis, H. 1988. Willingness to Pay (WTP) and Willingness to Accept (WTA) Measures In Turkey: May WTP and WTA Be Indicator To Share The Enviromental Damage Burdens: A Case Study. Journal of Economics Cooperation Among Islamic Counrty. 19(3), 76-93.

Verdian, E. 2019. Analisis Faktor Yang Mempengaruhi Intensi Perpindahan Merek transporatasi Online di Surabaya. AGORA. 7(1), 1-8.

Wisudanto \& Baihaqi. 2016. Perilaku Loss Aversion Kasus Pada Pasar Modal di Indonesia. Conference Managing Local Resources to Compete in The Global Market (FMI) 8 Palu. Vol.8, 1-12. 